Available Online at http://journal.unismuh.ac.id/index.php/otoritas

Otoritas : Jurnal Ilmu Pemerintahan, 7 (2), October 2017, 100-112

\title{
The Social Workers Challenges on Community Welfare in Ungongo Community, Nigeria
}

\author{
Kehinde Adekunle Aliyu*), Jamaluddin Mustaffa, Norruzeyati Che Mohd Nasir \\ School of Applied Psychology, Social Work and Policy, College of Arts and Sciences \\ Universiti Utara Malaysia, 06010 UUM Sintok, Kedah Darul Aman, Malaysia.
}

Received: 7 July 2017; Revised: 9 September 2017; Accepted: 5 October 2017

\begin{abstract}
The role of social workers in a community cannot be overemphasised by any mean, for the life span of any community depends on the quality of the social workers. The aim of this work is to affirm the roles of social workers in helping the community welfare. Qualitative research design was adopted for the work. Data collected with the Interview Schedule for Officials of the Federal Road Safety Corps and Interview Guide for selected group of people. This was administered to 30 respondents, which comprises both male and female in the Ungogo community. The purpose of the study was to examine the roles of social workers, in line with improved standards of living, sustained economic development and expansion of trade and economic relations in the community; enhanced levels of international competitiveness in the areas of community welfare, organization for increased productivity of people in the community. It common knowledge every individual strife to be the best when receive the necessary or adequate encouragement. To these extents, such a person bears some responsibilities even if passively so as a member. The implication of this work is to contribute to social change by informing social worker on their challenges and responsibilities ahead of them in the community.
\end{abstract}

Keywords: Community welfare; Social Workers; Challenges; Prevention

How to Cite: Aliyu, K. A., Mustaffa, J., Nasir, N. C. M. (2017). The Social Workers Challenges on Community Welfare in Ungogo Community, Nigeria. Otoritas : Jurnal Ilmu Pemerintahan, 7(2), 100-112.

Permalink/DOI: https://doi.org/10.26618/ojip.v7i2.761

${ }^{*}$ Corresponding Author.

E-Mail : aliyuadek@gmail.com

Copyright (C) 2017, Otoritas : Jurnal Ilmu Pemerintahan, ISSN: 2088-3706 (Print), ISSN: 2502-9320 (Online) 


\section{INTRODUCTION}

The government in any community internationally including Nigeria at all levels be it federal, state and local government should be committed to looking after the welfare of the members of that community and they go about this in a number of ways including making provision for social amenities and services available to better aid the public welfare. This belief tended to inspire a considerable indifference to the welfare, this led to introduction of welfare department that deals with all that concern human life from physical to emotional needs (Aworemi, Abdul-Azeez, \& Olabode, 2010). The public safety rules was to serve as a guide to all intended drivers and regulate their behaviour even while on the wheel. This shows that many people who seat behind the wheel are ignorant of these traffic rules and almost nothing is been done on this because most people still get drivers' license without appearing in person for examination and this continually make the road more on safe for every road users at all categories (Blomquist, 2012).

Road traffic accidents have been a major cause of deaths in Nigeria. An analysis of the accident data recorded over a ten-year period: 1990-1999 throws more light on the outcome of traffic accidents on the Nigerian roads. Public safety is a top concern to governments as well as citizens in all nations around the globe. (Aworemi, Abdul-Azeez, \& Olabode, 2010) Any committee of public safety in a community is committed to looking after the welfare of the members of that community and they go about this in a number of ways including making transportation and police services available to better aid the public. Some public safety concerns around the country include those concerns about crime and law enforcement which are both increasing in Nigeria. The law enforcement factor in public safety is one of the public safety jobs necessary for alleviating crimes and therefore increasing public safety (Olaide \& Iyiola, 2011).

Any community, no matter how underdeveloped, has its own economic activities, carried out by its members in order to better their lives and in turn better the community. Violating traffic rule is going against the stipulated guides that regulate the manner in which a driver conduct himself on the road, such as speed limit, overtaking, parking, etc. once any of these traffic rules are compromised then one can say they are violated. This paper highlights the issue of road traffic safety as an important community concern and discusses the roles social workers could play in sustaining safety of community members.

\section{RESEARCH METHODS}

Stratified random sampling technique was employed to select the sample size of 30 participants from Ungogo local government area of Kano state, which comprises of the Federal Road Safety Corps staffs and community members both male and female. Stratified random sampling is a method in which the researcher divides his population into strata by some characteristic which is known from previous research or theories to be related to the phenomenon under examination, and from each of these smaller homogeneous groups he draws at random a predetermined number of units (Riff, Lacy, \& Fico, 2014). The Interview Schedule known as "Road traffic Official Interview Guide" (RSOIG), concerns personal details of the officials of FRSC.

A combination of both descriptive and inferential statistics was used as techniques of data analysis for this study (Teddlie, \& Tashakkori, 2009). The fivepoint Likert-type rating scale was used in measuring responses to the questions stated in form of attitudinal statement. Hence, the data was categorized and 
scaled nominally. As part of the instrument of data analysis, weighted average was calculated where necessary and the objective isaffirm the roles of social workers in helping the community welfare.

\section{RESULT AND DISCUSSION}

At the end of the study the following major findings were identified that there are greater extent of violation of traffic rules and regulations in Ungogo LGA and Kano municipal in general, this show that majority of road users violate traffic rules knowingly or unknowingly to them which affect the community welfare. This study has revealed that indiscipline and corruption, enforcement problems like disobedience and disregard for law, poor driving habits, poor training, frequent friction and conflicting responsibility among different levels of government agencies over who to do what on the road. The data analysis also revealed that the vehicle operators fail to adhere to safety regulations, for example, fastening seatbelts and ensuring safe condition of the vehicle.

That little effort are being put in place to reduce the rate of violation by the road user, the major problem, licenses are issued without proper testing and corruption of government agencies. That majority of family suffers a greater consequences on the violation of traffic rules less awareness of road traffic rules and lack of proper training course on driving, has made so many family members lost their means of livelihood, the people of Ungogo local governments area are greatly affected by the violation of traffic rule to a greater extent in welfare of the community members.

The people of Ungogo local governments area are greatly affected socially by the violation of traffic rule having to take responsibility of feeding of the family members payment of the victims children's school fees, diversion of designated fund to catering for the victims to a greater extent in welfare of the community members. This section presents the finding and analysis of study two which is based on data collected from the series of interview conducted with 10 Federal Road Safety Corps (FRSC) staffs and 20 Ungogo community members in Kano, Nigeria. The analysis presents answers to the research objective, affirm the roles of social workers in helping the community welfare.

Table 1 shows that majority of road users violate rules of speed limit and overloading mostly, these among other traffic rules are mostly violated by drivers on the road generally and most of the offenders are warned while others are booked respectively according to the offenses committed. This show that majority of road users violate traffic rules knowingly or unknowingly to them. Some of the offers are referred to driving school for proper training and re-certification of drivers.

The men of FRSC on daily basis resume work on the Ungogo LGA 8.00 am and close $6.00 \mathrm{pm}$. This was discovered during the interview section with the officer of FRSC. The opinions of the respondents shows that they is a wide gap between the facts of FRSC and the people perhaps the people are more on the ground than that of the agencies that is responsible for safety on our road.

Table 2 shows that $51.5 \%$ of respondents lack awareness of traffic rules and regulations, while $36.7 \%$ blame it on the ineffectiveness of the agencies and $11.9 \%$ blamed it on drivers in experience. This is further explained in table 1 to 3 below.

A key issue in this research is ascertaining the respondents' awareness of the traffic rules. Hence, they were asked to indicate their level of awareness of each one of 10 listed driving rules. The responses were scored on a 5 point Likerttype rating scale ranging from scale 5 for "very high level of awareness" to 1 for "no awareness". The responses were subse- 
Available Online at http://journal.unismuh.ac.id/index.php/otoritas

Otoritas : Jurnal Ilmu Pemerintahan, 7 (2), October 2017, 103

quently summarized using weighted score (WS) and ranking as depicted in table 3 .

\section{Intrepretation}

Analysis revealed that awareness of Get too close to the vehicle in front ' ranked first with a weighted score of 124, followed by the Awareness of not using mobile phone while driving' ( $\mathrm{w}$-score = 108). Awareness of the use of it in the 'Not over speeding' ranked third with a weighted score of 105 . In decreasing order of ranking, the respondents were also aware of not overtaking dangerously (wscore $=104)$, 'having respect for other road users' (w-score $=97$ ), 'using seat belt while driving' (95) 'not being aggressive or arrogant to other road users' (92), and not parking indiscriminately' (w-score $=$ 88). Similarly, there was a relatively low level of awareness of the traffic rules: 'not overloading the vehicle' ( $\mathrm{w}$-score $=83$ ), and 'not driving under the influence of alcohol and drugs' (73). See the frequency distribution table above.

Further analysis revealed that majority of the respondents (12 or $40 \%$ ) have high level of awareness of traffic rules; (15 or $48 \%$ ) have moderate level of awareness while only 3 respondents $(12 \%)$ have low level of awareness of traffic rules.

An attempt was made to ascertain the means through which the respondents got to know how to drive. It is shown that majority of the respondents (12 or $40 \%$ ) got to know about traffic rules

Tabel 1. The Extent of Violation of Traffic Rules and Regulations

Source: FRSC (2013)

\begin{tabular}{llll}
\hline No & \multicolumn{1}{c}{ Types of Violation } & Number of violators & Percentage \\
\hline 1 & Over speeding & 1285 & $20.85 \%$ \\
2 & Wrong overtaking & 626 & $8.26 \%$ \\
3 & Driving under alcohol & 328 & $3.28 \%$ \\
4 & Overloading of the vehicle & 2234 & $32.43 \%$ \\
5 & Not using seat belt & 867 & $11.67 \%$ \\
6 & Using mobile phones while driving & 426 & $4.26 \%$ \\
7 & Driving recklessly & 205 & $2.05 \%$ \\
8 & Parking indiscriminately & 108 & $1.08 \%$ \\
9 & Leaving the scene of an accident & 58 & $0.58 \%$ \\
10 & Broken signals & 869 & $10.69 \%$ \\
11 & Under age driving & 209 & $2.09 \%$ \\
12 & No fire extinguisher and 'C' caution & 104 & $1.04 \%$ \\
\hline
\end{tabular}

Tabel 2. Reasons for Violating Traffic Rules and Regulations Source: Aliyu (2014)

\begin{tabular}{lll}
\hline \multicolumn{1}{c}{ Reasons } & Frequency & Percentage \\
\hline $\begin{array}{l}\text { Lack of awareness of traffic rules } \\
\begin{array}{l}\text { Ineffectiveness of agencies that are saddled with responsibility } \\
\text { of safety }\end{array}\end{array}$ & 17 & 51.50 \\
Drivers in experience & 3 & 36.60 \\
\hline
\end{tabular}


Available Online at http://journal.unismuh.ac.id/index.php/otoritas

Otoritas : Jurnal Ilmu Pemerintahan, 7 (2), October 2017, 104

while on the driving; (12 or $40 \%$ ) while in driving school, while only(6 or $20 \%$ ) got to know of it through relevant agencies. Thus, majority of the respondents were aware of traffic rules essentially through relevant agencies (i.e. driving institutes) or on the wheel, and to a rather less extent through driving school.

\section{Social Workers on Community Welfare}

It is highly challenging to be a social worker, but it is a rewarding career. Social workers are responsible for assisting individuals, families, and groups of people to cope with problems they are fronting to improve their patients' lives. One of the aspect of this is teaching skills and developing apparatuses for patients to rely on to better their lives and experiences (Sarason, 2013). Nevertheless, many social workers find that direct counseling of patients, families, and groups is only one little aspect of their broader set of responsibilities. Social workers will often serve as liaisons between different institutions to assist patients and collaborate with

Table 3. Lack Awareness of Traffic Rules and Regulation

Source: Aliyu (2014)

\begin{tabular}{|c|c|c|c|c|c|c|c|}
\hline \multirow[b]{2}{*}{ Driving Rules } & \multicolumn{7}{|c|}{ Level of Awareness } \\
\hline & $\begin{array}{l}\text { Very } \\
\text { often }\end{array}$ & Often & $\begin{array}{c}\text { Some } \\
\text { time } \\
s \\
\end{array}$ & $\begin{array}{c}\text { Rarel } \\
\mathbf{y}\end{array}$ & $\begin{array}{c}\text { Not } \\
\text { at all }\end{array}$ & $\begin{array}{l}\text { Weighted } \\
\text { score }\end{array}$ & Rank \\
\hline $\begin{array}{l}\text { Not having } \\
\text { respect for } \\
\text { other road } \\
\text { users }\end{array}$ & 10 & 6 & 3 & 3 & 8 & 97 & $5^{\text {th }}$ \\
\hline $\begin{array}{l}\text { Being } \\
\text { aggressive or } \\
\text { arrogant to } \\
\text { other road } \\
\text { users }\end{array}$ & 11 & 3 & 3 & 3 & 10 & 92 & $7^{\text {th }}$ \\
\hline Over speeding & 14 & 4 & 2 & 3 & 7 & 105 & $3^{\text {rd }}$ \\
\hline $\begin{array}{l}\text { Parking } \\
\text { indiscriminate }\end{array}$ & 10 & 3 & 3 & 3 & 11 & 88 & $8^{\text {th }}$ \\
\hline $\begin{array}{l}\text { Not overtaking } \\
\text { dangerous }\end{array}$ & 14 & 4 & 1 & 4 & 7 & 104 & $4^{\text {th }}$ \\
\hline $\begin{array}{l}\text { Using mobile } \\
\text { phone while } \\
\text { driving }\end{array}$ & 15 & 3 & 4 & 1 & 7 & 108 & $2^{\text {nd }}$ \\
\hline $\begin{array}{l}\text { Not using seat } \\
\text { belt while } \\
\text { driving }\end{array}$ & 10 & 6 & 3 & 1 & 10 & 95 & $6^{\text {th }}$ \\
\hline $\begin{array}{l}\text { Driving under } \\
\text { the influence of } \\
\text { alcohol and } \\
\text { drugs }\end{array}$ & 6 & 4 & 2 & 3 & 15 & 73 & $10^{\text {th }}$ \\
\hline $\begin{array}{l}\text { Overloading the } \\
\text { vehicle }\end{array}$ & 8 & 4 & 3 & 3 & 12 & 83 & $9^{\text {th }}$ \\
\hline $\begin{array}{l}\text { Get too close to } \\
\text { the vehicle in } \\
\text { front }\end{array}$ & 17 & 6 & 3 & 2 & 2 & 124 & $1^{\text {st }}$ \\
\hline
\end{tabular}


other health professionals to ensure patient wellness and recovery.

They will become acquainted with, and refer clients to, community resources. Social workers address legal issues, such as assisting with hearings and providing testimony relating to their patients in either court of law or where the clients need assistance. They also engage in research, policy development and advocacy for services (Cipolle, 2010). Moreover, social workers must maintain case history records and prepare reports on every case handled by them. Social work can be the kind of job that requires a great deal of overtime, and separating the emotional aspects of the job from the duties required can be a difficult undertaking.

Social workers are very important change agents who also ensure that community members are well care for and made them to understand their challenges and are ready to solve the problems for them (Pittman, Irby, Tolman, Yohalem, \& Ferber, 2011). As an important person, it requires dedication is to make the people aware of various problems in a community. They help to provide knowledge and to know about the main causes that affect their life in a given community.
In dealing with the assembly of challenges that social workers address, they must employ a variety of qualities depending on the job that needs to be done (Herzberg, Mausner, \& Snyderman, 2011). While some of these skills may be natural, some of them are improved while a social worker earns his or her bachelor's, master's or PhD degrees.

Some of the qualities are enumerated like active listening, critical thinking, complex problem solving, coordination, judgement and decision making, Reading Comprehension,social perceptiveness, speaking, service orientation, and writing.

\section{Factors That Cause Traffic Accidents}

According to Aliyu (2014), most tragic accidents often involve all the three elements. Often the person is involved with only one of the other two elements or factors. Most road traffic accidents (RTA) involve motor vehicles, but bicycle or pedestrian accidents can occur without motor vehicles. It has however, been observed that most of the factors involved in road traffic accident are created or controlled by man. For instance, table 4 shows traffic violation that most time resort into road traffic accidents.

Table 4. Opinion of respondents regarding extent of violation of traffic rules and regulations Source: Aliyu (2014)

\begin{tabular}{llll}
\hline \multicolumn{1}{c}{ Types of offenses } & Low & $\begin{array}{c}\text { Extent } \\
\text { High }\end{array}$ & $\begin{array}{c}\text { Very } \\
\text { High }\end{array}$ \\
\hline Over speeding & & - & 1000 \\
Wrong overtaking & - & 600 & - \\
Driving under alcohol & - & 550 & - \\
Overloading of the vehicle & 120 & - & - \\
Not using seat belt & 130 & - & - \\
Using mobile phones while driving & - & 200 & - \\
Driving recklessly & - & 580 & - \\
Parking indiscriminately & - & 680 & - \\
Leaving the scene of an accident & 80 & - & - \\
Broken signals & 140 & - & - \\
Under age driving & 128 & - & - \\
No fire extinguisher and 'C' caution & - & 290 & - \\
\hline
\end{tabular}


The table 4 shows that majority of road users violate driving rules, such as; speed limit and overloading, these among other traffic rules are mostly violated by drivers on the road generally and most of the offenders are sometime indifferent to warning while others are less cared if booked respectively according to the offenses committed. This show that majority of road users violate traffic rules knowingly or unknowingly to them. Some of the offers are referred to driving school for proper training and re-certification of drivers. But the result of these violations is enormous or of great consequence to the community, (Road traffic accident is either you are affected or some close to you in the community is) you are either a pedestrian, a passenger or a driver (Aliyu, 2014).

Man initiates the process that may yield a road traffic accident (RTA) by travelling. He or she may travel as a pedestrian, as a passenger in a vehicle or as the operator of a vehicle. To these extents, such a person bears some responsibilities even if passively so as a passenger. The role of intoxication with drugs and alcohol is important in the road traffic accidents worldwide. It is common knowledge that the consumption of these intoxicating agents is voluntary. Vehicle operators may also neglect to ensure the roadworthiness of their vehicles before they hit the highway (Madubueze, Chukwu, Omoke, Oyakhilome, \& Ozo, 2011).

Occasionally, the vehicle operators fail to adhere to safety regulations, for example, fastening seatbelts and ensuring safe condition of the vehicle. It is however, difficult to obey these regulations in the developing nations. Over-speeding, overtaking at dangerous corners, impatience of the driver and other human elements in road traffic accidents. It has also been observed that during the festive periods and holidays, there are always more vehicles on the Nigerian highways and roads rushing to meet certain commitments or arrive at their destinations. Consequently, there are more accidents during these periods than at other times.

There are still other factors associated with RTA. These are poor road conditions, inadequate traffic warnings and bad weather conditions especially during the rainy season and harmattan period.

\section{Strategies for the Prevention/Control of Road Traffic Accidents in the Com- munity}

It is against the foregoing background of traffic accidents on the Nigerian highways and roads that the following preventive strategies are suggested driver training should be supervised by qualified personnel and law enforcement agencies who are well knowledge on the subject matter. Driving licenses should be issued under strict and impartial compliance with the government rules and regulations in conformity with international standard.

Use of seatbelts by all motorists should be demanded and enforced always but not occasionally as we see on our roads (Brackstone, Waterson, \& McDonald, 2009). Motor vehicles should be inspected to ensure their roadworthiness before each registration. Inspection checklist should include rear view mirrors, side view mirrors, wind screen wipers, speedometer, brakes and brake lights, trafficators, reverse lights, license plate lights, parking light.

The vehicle inspection officials (VIO's) are yet to record impressive achievements in this area. A brief comment under this strategy is in order. There have always been the vehicle inspection officials (VIO's). Perhaps, because these were overworked, but more likely because ineptitude or corruption had rendered them ineffective with regard to ensuring the roadworthiness of vehicles, the Federal Road Safety Corps (FRSC) was formed in 1982 and officially 
Available Online at http://journal.unismuh.ac.id/index.php/otoritas

Otoritas : Jurnal Ilmu Pemerintahan, 7 (2), October 2017, 107

Table 5. Creating Awareness on Activities of Agencies

Source: Aliyu (2014)

\begin{tabular}{|c|c|c|c|c|c|c|c|}
\hline \multirow[t]{2}{*}{ Performance } & \multicolumn{7}{|c|}{ Extent of Awaraness Usage Level } \\
\hline & $\begin{array}{l}\text { Very } \\
\text { high }\end{array}$ & High & Few & Little & Nothing & $\begin{array}{l}\text { Weighted } \\
\text { score }\end{array}$ & Rank \\
\hline $\begin{array}{lr}\text { Managing } & \text { / } \\
\text { preparing intending } \\
\text { drivers r before } \\
\text { insurance driver's } \\
\text { license to the } \\
\text { persons }\end{array}$ & 14 & 4 & 1 & 4 & 7 & 104 & $4^{\text {th }}$ \\
\hline $\begin{array}{l}\text { Regulatory / } \\
\text { mandatory rules are } \\
\text { basic rules on the } \\
\text { road }\end{array}$ & 15 & 3 & 4 & 1 & 7 & 108 & $2^{\text {nd }}$ \\
\hline $\begin{array}{l}\text { Loading, unloading, } \\
\text { overloading and } \\
\text { consideration for } \\
\text { other road users }\end{array}$ & 10 & 6 & 3 & 1 & 10 & 95 & $6^{\text {th }}$ \\
\hline $\begin{array}{l}\text { Special safety hints: } \\
\text { stopping distances } \\
\text { under any condition } \\
\text { and common causes } \\
\text { of road accident }\end{array}$ & 17 & 6 & 3 & 2 & 2 & 124 & $1^{\text {st }}$ \\
\hline $\begin{array}{l}\text { Vehicle } \\
\text { maintenance } \\
\text { protection and } \\
\text { driver's protection } \\
\text { on the road }\end{array}$ & 14 & 4 & 2 & 3 & 7 & 105 & $3^{\mathrm{rd}}$ \\
\hline $\begin{array}{l}\text { Overtaking rules, } \\
\text { pavement messages } \\
\text { and single / dual } \\
\text { carriageway } \\
\text { discipline }\end{array}$ & 10 & 3 & 3 & 3 & 11 & 88 & $8^{\text {th }}$ \\
\hline $\begin{array}{l}\text { Maintaining speed } \\
\text { limits in built up } \\
\text { areas and highways }\end{array}$ & 10 & 6 & 3 & 3 & 8 & 97 & $5^{\text {th }}$ \\
\hline $\begin{array}{l}\text { Adequate } \\
\text { awareness on the } \\
\text { part of the drivers } \\
\text { by the relevant } \\
\text { agencies }\end{array}$ & 8 & 4 & 3 & 3 & 12 & 83 & $9^{\text {th }}$ \\
\hline $\begin{array}{l}\text { Vehicle inspection } \\
\text { officer checks all } \\
\text { vehicles to know } \\
\text { whether they are } \\
\text { road worthy or not }\end{array}$ & 6 & 4 & 2 & 3 & 15 & 73 & $10^{\text {th }}$ \\
\hline $\begin{array}{l}\text { Fire fighters are } \\
\text { well trained to } \\
\text { rescue victims of } \\
\text { accidents on our } \\
\text { roads }\end{array}$ & 11 & 3 & 3 & 3 & 10 & 92 & $7^{\text {th }}$ \\
\hline
\end{tabular}


inaugurated in 1995. The full time operators are designated Road Marshalls. In spite of induction of volunteer senior civil servants, company executives and the academia as special marshals to boost morale and number, the FRSC soon tended towards the ways of the VIO's. The outfit according to Aworemi, Abdul-Azeez, \& Olabode, (2010) soon lost its focus and became a political pawn.

Nigerian citizens should be formally educated about the effect of drugs and alcohol on driving ability. Education at the primary, secondary and tertiary levels should include instruction on alcohol and drug in their health education curricula. The long-term benefit of this strategy is sure to improve future during performance which in turn will reduce the number and severity of traffic accidents on the Nigerian highways. Aliyu, (2014) stated that, in view of the fact that a large number of the Nigerian drivers cannot read or write English Language, the road signs should be expressed in pictorial language, English and other local languages to enable such drivers operate safety in their localities. This measure if implemented with care and commitment should enhance driving performance for the benefit of the vehicle drivers and non-drivers.

The governments of Nigeria should pay more attention to the maintenance of their highways and roads for safe use of the motorists and the general public. What should be the role of community development workers in ensuring safety in the community, we should take critical look at the table 5 .

Analysis of the procedures adopted show that the respondents in becoming more aware of the task of the relevant agencies. The summary of the results is presented in the table 5 showed that the awareness of community member on the listed items is low. 'Special safety hints: stopping distances under any condition and common causes of road accident' ranked first with a weighted score of 124 .
This was followed by 'regulatory / mandatory rules are basic rules on the road' (ws = 108).; 'vehicle maintenance / protection and driver's protection on the road' (ws = 105); 'managing / preparing intending drivers before insurance driver's license to the persons' (ws = 104);'maintaining speed limits in built up areas and highways' (ws $=97$ ) in decreasing order. 'Loading, unloading, overloading and consideration for other road users' ranked 6th with a weighted score of (ws $=95$ ). Next to this and in decreasing order are: 'fire fighters are well trained to rescue victims of accidents on our roads' (ws= 92); and 'overtaking rules, pavement messages and single / dual carriageway discipline'(ws = 88)Similarly, there was a relatively low level of awareness on the part of the drivers by the relevant agencies' (ws = 83), and 'vehicle inspection officer checks all vehicles to know whether they are road worthy or not' (we = 73).

\section{The Role of Social Workers in Ensuring Safety in the Community}

The basic goal or role of social worker might be defined as a work function which encapsulates a particular approach or set of tasks which others can reasonably expect the worker to perform. The community worker has a variety of roles, which can be broadly categorised into eight main functions: organiser, advocate, challenger, encourager, developer, educator and supporter (Bishop, 1970). These can be arranged on a continuum from directive intervention to an active, but non $\neg$ directive approach. The role which the worker plays on any occasion depends on a range of factors at a given situation, but most importantly on how it can help other people to get things done.

There are several important points that must be implemented in relation to the role of social workers in ensuring safety in the community. Implementation of driving education and traffic safety 
among drivers is an first important thing to do.

Driver and traffic safety education is a normative enterprise growing out of man's problems. These problems arise from improper co-ordination among the three big traffic elements: namely the driver (human), the highway and the motor vehicle. Research evidence indicates that the human element is responsible for 80 to $85 \%$ of all traffic accidents. Traffic violations, driving while intoxicated and lack of driving courtesy are the results of human actions. Unsafe highway and road conditions cause about $10 \%$ of all traffic accidents while mechanical deficiencies are responsible for nearly $5 \%$ of all traffic problems (Moen, Kelly, \& Lam, 2013).

The next is stating clearly the function of drivers and traffic safety education, the function of Driver and Traffic Safety Education is to help students and other individuals to learn using motor vehicles safely and efficiently. It achieves this function by coordinating properly, the three big traffic elements. Driver and traffic safety education should be offered at the primary and secondary school levels in Nigerian schools. Instructions are given in the classroom and during road practice. The primary school children cannot drive but constitute members of the traffic system. They should be made aware of their traffic environment (Madubueze, Chukwu, Omoke, Oyakhilome, \& Ozo, 2011). The level of driver education offered at the primary school level should whet the learner's appetite for its pursuit at the secondary school level. Driver and traffic safety education should, also, be offered in post-secondary institutions to train driver educators

The next is the importance of Emphasis the importance of driver and traffic safety education to the community. Driver and Traffic Safety Education is important to Nigeria in the following ways driver and Traffic Education will educate the youth about themselves in respect of their capabilities and limitations in the use of motor vehicles, the automobiles - their capacities as well as their limitations and the highways on which they operate. Their knowledge of these three traffic elements can make them become better and considerate road users. Better and considerate driving is apt to reduce the number of disasters on the Nigerian highways. Driver and Traffic Safety Education will equip the youth for and open doors to new careers or vocations they would never have conceived of without such education (American Automobile Association, 1988 and Driver Education Products, ND).

The growth and development of a nation depends, largely, upon the capacity of its transport system to move persons and goods to desired locations safety (Mayhew, 2007). This is true of Nigeria, and co-ordination for success within its highway system can only be achieved through driver and traffic safety education (Aliyu, 2014).

In ensuring public safety also needs to be supported with good capacity building and role capability as social workers. social workers are required to be the organizer, advocate, challenger, developer, and supporter in the social services provided.

Social worker as an organizer can be interpreted that on the beginning stages of helping a group to set up, the social worker may adopt the rather directive role of organizer, taking the responsibility for getting things started by arranging meetings, sending out publicity, organizing positive action measures, such as childcare and interpreting arrangements on how to driver conduct themselves either by driving or not (Cipolle, 2010). Often community workers will do much of the "behind the scenes" organizing a group, following up contacts, undertaking administrative tasks, such as bookkeeping, servicing meetings, producing an orientation program or generally ensuring that the group members maintain con- 
tact with one another or check on themselves.

So is when Social workers as an advocate. This should be a rare role for social workers, whose aim is usually to enable people to speak for themselves and develop a collective voice in negotiating situations. Sometimes, however, there are constraints or pressures which justify the worker speaking on behalf of others to argue for a position based on a degree of consultation and consensus. Circumstances which might support this option might be lack of time in the decision-making process before the people affected by a decision have had time to gain the confidence and skills to articulate their own views in what might be an intimidating forum. The worker should be careful in the role of advocate that they do not go beyond their mandate to represent the views of others in the sight of the law or the enforcement agencies (Cireşan, Meier, Masci, \& Schmidhuber, 2011).

In addition to organizer and advocate, social workers are expected to play the role of challenger. One of the chief purposes of social worker is to change things, particularly to question and combat current inequalities in the distribution in the system. The worker therefore sometimes has a role to play in challenging prejudices, practices or policies that affect the community safety in discriminating against some drivers in the society. People often hold attitudes and assumptions about themselves and others which perpetuate disadvantage and oppression. These might be expressed through language which is offensive or through hostile or patronising behaviour (Aliyu, 2014). The community worker should challenge these (and enable others to do so for themselves) in a variety of ways, including humour, private discussion, open debate, policy proposals and modelling anti-oppressive practices. In adopting this role, the worker must also be prepared to deal with any conflicts, resent- ment or feelings of disempowerment that result and to recognise that the role of challenger can be both uncomfortable and controversial.

The next point is that social workers are required to act as developers. The social worker should usually be trying to move their professional relationship with users to be more that of developer or initiator. The key aspect to this role is that the worker is enabling the people he/she is working with to acquire new capabilities and to enhance their existing skills, knowledge and understanding of the general public safety. This process might be through encouraging people to share these with others in the group, learning through role play or observation or through more formal training opportunities. Often this involves working closely alongside individual members of a group on a particular task, giving practical advice, support and feedback so that they eventually feel confident to perform the task on their own (Pittman, Irby, Tolman, Yohalem, \& Ferber, 2011). Informal discussions or workshops also provide opportunities for people to share and develop their knowledge by reflecting on their own experience and gaining information on specific areas on public safety life such as the workings of local government.

terakhir, Social workers as a supporter. This role involves more interpersonal methods of working, such as counselling, advising, building self-esteem and generally encouraging people to work through difficult situations. It might include talking through an idea or a problem with an individual or group, listening to someone's grievances, staying in touch with a member of a group who is experiencing difficulties in their life and not able to attend regularly, being a friendly and accessible point of contact between people in the community and your employing organisation or simply ensuring that people can make use of facilities and resources that they need in their work 
Available Online at http://journal.unismuh.ac.id/index.php/otoritas

Otoritas : Jurnal Ilmu Pemerintahan, 7 (2), October 2017, 111

(such as use of a telephone, photocopier or meeting space.)

When in the role of supporter, contact between the worker and community users will normally be on the initiative and terms of the user. As such the worker will not have specific goals other than to provide emotional and practical support for the community in their chosen course of action in terms of their safety. Although research on traumatized people is outside the scope of this work, it is important to recognize that a range of trauma the victims of accident or relatives go through is more excruciating that cannot waved aside but be identified in this community. Research on the psychobiology of accident victims' trauma can be profitably informed by the vast literature on the psychobiological effects of relative of the victims on trauma and deprivation of life (Terwase, Abdul-Talib, Zengeni, \& Terwase, 2015).

\section{CONCLUSION}

It is observed that motor vehicles are becoming giant killer weapons in the hands of untrained Nigerian drivers. Tragedies associated with traffic accidents are difficult to assess in monetary terms. The proposed intensive and continuous training and retraining of drivers, with its promising features, into our schools and society system in which social worker is highly needed, deserves serious consideration by the Nigerian governments both at all levels; Federal, State and Local government. The training of our primary, secondary and post-secondary learners and the distance learners in education for traffic safety today means entrusting the driving business into good hands for tomorrow better life. Time is ripe for action from the carrier of community spirit the social workers.

\section{ACKNOWLEDGEMENT}

The author thanks to colleague in Universiti Utara Malaysia for their support to success this work. hopefully this article can provide benefits for the development of community service studies.

\section{REFERENCES}

Aliyu, K. A. (2014). Effects of road traffic violation on public safety (Masters Dissertation, Bayero University Kano).

Aworemi, J. R., Abdul-Azeez, I. A., \& Olabode, S. O. (2010). Analytical study of the causal factors of road traffic crashes in southwestern Nigeria. Educational research, 1 (4), 118-124.

Bishop, D. W. (1970). Stability of the factor structure of leisure behavior: Analyses of four communities. Journal of Leisure Research, 2(3), 160.

Blomquist, G. C. (2012). The regulation of motor vehicle and traffic safety. Springer Science \& Business Media.

Brackstone, M., Waterson, B., \& McDonald, M. (2009). Determinants of following headway in congested traffic. Transportation Research Part F: Traffic Psychology and Behaviour, 12(2), 131-142.

Cipolle, S. B. (2010). Service-learning and social justice: Engaging students in social change. Rowman \& Littlefield Publishers.

Cireşan, D., Meier, U., Masci, J., \& Schmidhuber, J. (2011, July). A committee of neural networks for traffic sign classification. In Neural Networks (IJCNN), The 2011 International Joint Conference on (pp. 19181921). IEEE. 
Herzberg, F., Mausner, B., \& Snyderman, B. B. (2011). The motivation to work (Vol. 1). Transaction publishers.

Madubueze, C. C., Chukwu, C. O. O., Omoke, N. I., Oyakhilome, O. P., \& Ozo, C. (2011). Road traffic injuries as seen in a Nigerian teaching hospital. International orthopaedics, 35(5), 743-746.

Mayhew, D. R. (2007). Driver education and graduated licensing in North America: Past, present, and future. Journal of safety research, 38 (2), 229-235.

Moen, P., Kelly, E. L., \& Lam, J. (2013). Healthy work revisited: do changes in time strain predict wellbeing?. Journal of occupational health psychology, 18(2), 157.

Olaide, 0. \& Iyiola O. (2011).“Traffic safety in a developing economy" paper presented during the 2011 Special Marshal Sectoral Workshop, University of Lagos, Nigeria.

Pittman, K. J., Irby, M., Tolman, J., Yohalem, N., \& Ferber, T. (2011, December). Preventing problems, promoting development, encouraging engagement. In Washington, DC: Forum for Youth Investment.

Riff, D., Lacy, S., \& Fico, F. (2014). Analyzing media messages: Using quantitative content analysis in research. Routledge.

Sarason, I. G. (Ed.). (2013). Social support: Theory, research and applications (Vol. 24). Springer Science \& Business Media.

Teddlie, C., \& Tashakkori, A. (2009). Foundations of mixed methods research: Integrating quantitative and qualitative approaches in the social and behavioral sciences. Sage.

Terwase, I. T., Abdul-Talib, A. N., Zengeni, K. T., \& Terwase, J. M. (2015). The Psychological Trauma on Boko Haram Victims in Nigeria: Conflict Resolution Perspective. Mediterranean Journal of Social Sciences, 6(6 S4), 519. 